J. Clin. Chem. Clin. Biochem.

Vol. 18, 1980, pp. $917-920$

\title{
Electroimmunoassay and Radioimmunoassay for the Quantitation of High Density Apolipoproteins A-I and A-II
}

\author{
By R. C. Mordasini
}

Institute for Clinical Protein Research, University of Berne, Switzerland and

W. F. Riesen

Institute for Clinical Cancer Research, University of Berne, Switzerland

(Received October 26, 1979/April 3, 1980)

Summary: An electroimmunodiffusion assay (EID) for the quantitative determination of the major apolipoproteins of the human high density lipoprotein fraction, apolipoproteins A-I and A-II, was compared with a solid phase radioimmunoassay (RIA), previously described by us. Data obtained by both methods largely depended on the pretreatment of the sera. Pretreatment consisted either of delipidation with an ether/ethanol mixture or tetramethyl urea, or of denaturation by heating the sera to $52^{\circ} \mathrm{C}$ for 3 hours. Delipidation with ether/ethanol produced a decrease of apolipoprotein A-I values in both methods as compared to treatment with tetramethyl urea. In contrast, the ether/ ethanol treatment did not alter apolipoprotein A-II values in the RIA, while in the EID this procedure led to an increase of apolipoprotein A-II values. Heating gave an increase of both apolipoproteins A-I and A-II in both assays, but results obtained by EID were difficult to interpret because of the appearance of indistinct or double rockets. Comparable results by both methods were obtained, when sera were pretreated with tetramethyl urea. Handling and reproducibility seemed to be slightly better with the EID than with the RIA.

\section{Vergleich zwischen Elektroimmunoassay und Radioimmunoassay zur Bestimmung der Apolipoproteine A-I und A-II}

Zusammenfassung: Ein Elektroimmunodiffusionstest (EID) zur quantitativen Bestimmung der häufigsten Apoproteine der menschlichen High Density Lipoprotein Fraktion, Apolipoprotein A-I und A-II, wurde mit dem von uns früher beschriebenen Festphasen-Radioimmunoassay (RIA) verglichen. Die Resultate, welche mit den beiden Methoden erhalten wurden, hingen in hohem Maße von der Vorbehandlung der Seren ab. Die Vorbehandlung bestand entweder aus der Delipidierung mit einem Ether/Ethanol-Gemisch oder mit Tetramethyl-Harnstoff oder aus Erhitzen auf $52^{\circ} \mathrm{C}$ während 3 Stunden. Die Delipidierung mit Ether/Ethanol führte bei beiden Methoden zu einer Erniedrigung der Apolipoprotein A:I-Werte gegenüber Werten, welche nach Tetramethyl-Harnstoff-Behandlung erhalten wurden. Die mit RIA erhaltenen Apolipoproteị A-II-Werte erfuhren dagegen durch die Ether/Ethanol-Behandlung keine Änderung, währeñ beim EIA, im Gegensatż zu Apolipoprotein A-I, eine Erhöhung der Apolipoprotein A-II-Werte festgestellt wurde. Dás Erhitzen der Seren ergab bei beiden Methoden eine Erhöhung sowohl der Apolipoprotein A-I- wie der Apolipoprotein A-II-Werte, wobei beim EID die Ressultate schwer interpretierbar waren, weil undeutliche oder doppelte „Rockets" auftraten. Vergleichbare Resultate bei beiden Methoden wurden erhalten, wenn die Seren mit Tetramethyl-Harnstoff vorbehandelt wurden. Die Handhabung und die Reproduzierbarkeit schienen beim EID besser als beim RIA zu sein.

\section{Introdüction}

Recent evidence has indicated that it is probably not so much the lipid portion which makes a particular lipoprotein harmful to the arteries, but rather its apolipoprotein composition. It is well established that serum low density lipoproteins (LDL) are highly atherogenic, whereas serum high density lipoproteins (HDL) seem to exert a protective effect against coronary heart disease $(1-3)$.

The quantitative determination of the different apoproteins and its relationship to metabolic disorders is therefore an important goal of today's lipoprotein diagnostics. While the quantitation of apolipoprotein B, the apolipoprotein of LDL has become a routine 
analysis, for which a commercial test kit is available, the quantitation of the other apoproteins still poses considerable problems.

Several assays for the quantitative determination of apolipoproteins A-I and A-II, the two major apolipoproteins of $\mathrm{HDL}$, have been published during the last few years (4-9). The objective of this study was to compare an electroimmunoassay (EID) for apolipoproteins A-I and A-II with our previously described radioimmunoassay (RIA) (9).

\section{Materials and Methods}

\section{Serum samples}

Sera were taken from normolipidemic adults after a 12 hours fast. The sera were used either non-treated or delipidated with ether/ethanol (10) or with 1,1,3,3,-tetramethyl urea (11), or they were heated to $52^{\circ} \mathrm{C}$ for 3 hours in siliconized vials (5). Non-treated or ether/ethanol delipidated sera were diluted with the buffers used for RIA or EID, respectively. Sera delipidated with tetramethyl urea were diluted with Trisurea buffer, $\mathrm{pH} 8.0$, containing $0.01 \mathrm{~mol} / 1$ Tris, and $8 \mathrm{~mol} / 1$ urea (8).

\section{Antigen and antisera preparation}

$\mathrm{HDL}$ was isolated from individual donors by sequential ultracentrifugation (12) and repeatedly delipidated with 4 volumes acetone (twice), heptane (twice), ether/ethanol (11) twice and ether (once). The residue was finally dried under $\mathrm{N}_{2}$. The delipidated HDL was filtered on Sephadex G-150 in $6 \mathrm{~mol} / 1$ urea, $0.03 \mathrm{~mol} / \mathrm{l}$ Tris- $\mathrm{HCl}, \mathrm{pH} 8.2$ (13) and rechromatographed on DEAE cellulose in $6 \mathrm{~mol} / \mathrm{l}$ urea $(14,15,16)$. Antisera against apolipoproteins A-I and A-II were raised in sheep as previously described (9). Specific anti-apolipoprotein A-I antibodies were isolated over an immunoadsorbent consisting of apolipoprotein A-I. In the case of anti-apolipoprotein A-II the antisera were extensively adsorbed over several immunoadsorbents consisting of apolipoprotein A-I, human albumin, immunoglobulins, and various standards for immunodiffusion plates (Behringwerke, Marburg/Lahn), containing no HDL, which had been coupled to Sepharose 4B. The gammaglobulin fraction of this antiapolipoprotein A-II antiserum was prepared by precipitation with ammonium sulfate at 0.35 saturation. Both antibody preparations were monospecific as tested by immunoelectrophoresis and by double diffusion in agar against whole human serum, human serum albumin, LDL, apolipoprotein A-I and apolipoprotein A-II.

\section{Assay procedure}

The solid phase radioimmunoassay for apolipoprotein A-I and apolipoprotein A-II using bromoacetylcellulose was described previously (9). For the electroimmunodiffusion assay the following procedure was employed: $1.5 \mathrm{~g}$ of agarose was mixed with $50 \mathrm{ml}$ diethyl-barbiturate buffer $\mathrm{pH} 8.2$, $\mu=0.1,50 \mathrm{ml}$ water and $10 \mathrm{mg}$ sodium ethylmercurithiosalicylate. The mixture was heated to about $100^{\circ} \mathrm{C}$ until it became a clear solution. Five $\mathrm{ml}$ of this agarose stock solution were mixed with $5 \mathrm{ml}$ of buffer solution containing $0.8 \mathrm{mg}$ of isolated anti-apolipoprotein A-I antibodies, or $15 \mathrm{mg}$ of antiapolipoprotein A-II gammaglobulins respectively, and poured onto glass plates $(12 \mathrm{~cm} \times 5 \mathrm{~cm})$. After gelation the plates were stored in a moisture chamber at $4{ }^{\circ} \mathrm{C} .4 \mu \mathrm{l}$ of serum or standard were applied per well and electrophoresis was performed with cooling for 2 hours at $40 \mathrm{~mA}$ per plate. After electrophoresis the plates were dried and stained with amido black $10 \mathrm{~B}$, or with oil red.

\section{Apolipoprotein A-I and A-II standards}

Purity of apolipoprotein A-I and A-II preparations was assessed by SDS polyacrylamide gel electrophoresis, by isoelectric focusing, using a $\mathrm{pH}$ gradient from 3 to 10 , and by immunoelectrophoresis againist anti-whole human serum and anti- $\alpha_{1}$ lipoprotein (Behringwerke, Marburg/Lahn).

Concentration of apolipoprotein A-I and A-II was determined according to Lowry et al. (18), using bovine serum albumin, fraction V (Pentex, Miles Laboratory, Kankakee, Ill.) as the standard.

\section{Results}

The mean concentrations of apolipoprotein A-I and A-II as determined by EID and RIA for 50 males and 50 females between 20 and 60 years old are displayed in table 1 . Results from both methods were obtained with sera which were delipidated with tetramethyl urea prior to analysis. The data show that both methods, EID and RIA, give comparable results for apolipoprotein A-I and A-II, although the EID seems to give slightly higher apolipoprotein A-I values. Good agreement between both methods is furthermore substantiated by a correlation coefficient of 0.92 for apolipoprotein A-I and 0.94 for apolipoprotein A-II, respectively.

Since important changes in immunoreactive apolipoprotein A-I upon delipidation or heating and upon storage have been reported $(5,6)$ we studied the influence of several treatments on both the apolipoprotein A-I and the apolipoprotein A-II values as determined by either EID or RIA. The respective data are shown in table 2 and figure 1 . In the RIA, native sera and sera delipidated with tetramethyl urea seem to give approximately the same results for both apolipoprotein A-I and A-II. Delipidation with an ether/ethanol mixture leads

Tab. 1. Concentration of apolipoproteins A-I and A-II in normal sera as determined by EID and RIA after pretreatment with tetramethyl urea.

\begin{tabular}{llll}
$\begin{array}{l}\text { Apolipoprotein A-I } \\
(\mathrm{mg} / \mathrm{l})\end{array}$ & \multicolumn{3}{l}{$\begin{array}{l}\text { Apolipoprotein A-II } \\
(\mathrm{mg} / \mathrm{l})\end{array}$} \\
EID & RIA & EID & RIA \\
\hline $1130 \pm 90$ & $1070 \pm 110$ & $340 \pm 40$ & $330 \pm 40$ \\
$1250 \pm 170$ & $1^{\prime} 200 \pm 190$ & $360 \pm 50$ & $370 \pm 60$ \\
\hline
\end{tabular}

$\begin{array}{lllll}\text { Males } \quad(n=50) & 1130 \pm 90 & 1070 \pm 110 & 340 \pm 40 & 330 \pm 40 \\ \text { Females }(n=50) & 1250 \pm 170 & 1200 \pm 190 & 360 \pm 50 & 370 \pm 60\end{array}$

Tab. 2. Influence of various pretreatments on apolipoproteins A-I and A-II values as determined by EID and RIA.

\begin{tabular}{llrll}
\hline Pretreatment & $\begin{array}{l}\text { Apolipoprotein } \\
\text { A-I (mg/l) } \\
(\mathrm{n}=20)\end{array}$ & $\begin{array}{l}\text { Apolipoprotein } \\
\text { A-II (mg/l) } \\
(\mathrm{n}=20)\end{array}$ \\
& EID & RIA & EID & RIA \\
\hline None & 1100 & 1060 & 370 & 350 \\
Tetramethyl urea & 1180 & 1120 & 360 & 350 \\
Ether/ethanol & 990 & 970 & 400 & 360 \\
Heating to 52 ${ }^{\circ} \mathrm{C}$ & 1370 & 1320 & 420 & 400 \\
\hline
\end{tabular}




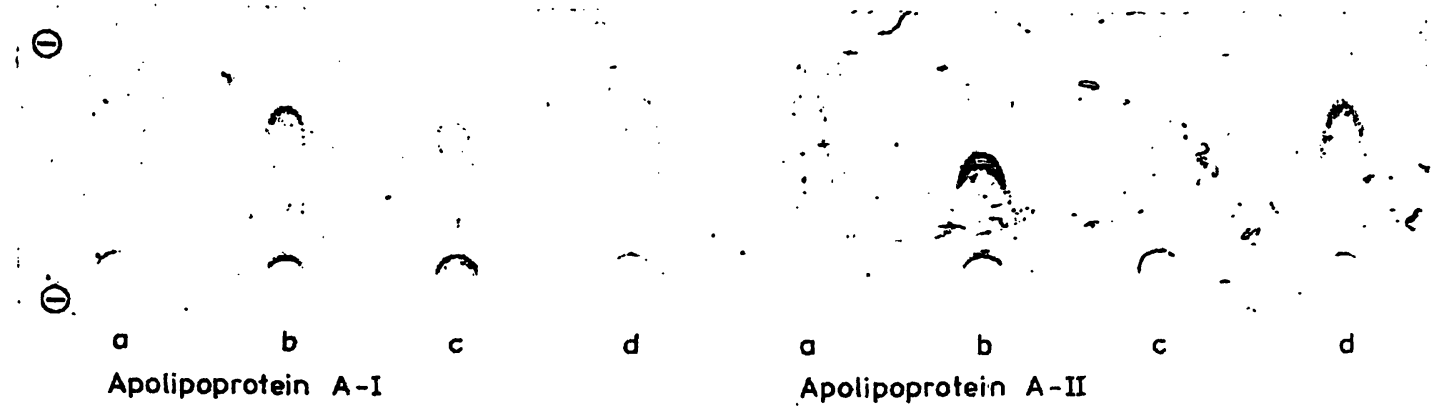

Fig. 1. Electroimmunoassay of apolipoprotein A-I and A-II.

The serum was pretreated as described in Materials and Methods.
a) native serum
b) 1,1,3,3-tetramethyl urea
c) ether/ethanol
d) heated to $52^{\circ} \mathrm{C}$ for 3 hours

to about 15 per cent lower apolipoprotein A-I values. In the EID a similar decrease of apolipoprotein A-I values is noted after delipidation with ether/ethanol. Apolipoprotein A-II values do not seem to be influenced by this treatment in the RIA. However, in the EID, apolipoprotein A-II values are considerably increased after delipidation with ether/ethanol. In accordance with a previous report (5), a net increase of apolipoprotein A-I values as determined by RIA is obtained when sera are heated to $52{ }^{\circ} \mathrm{C}$ for 3 hours prior to analysis. According to our experience this is not only the case for apolipoprotein A-I but also for apolipoprotein A-II values as determined by either RIA or EID. This increase varies from one serum to another in the order of 10 to $50 \%$, the mean increase being $20 \%$. In the $\mathrm{EID}$, rockets with heated or with untreated sera were not very distinct (fig. 1).

In both cases, occasionally even double rockets appeared notably in the case of apolipoprotein A-I, the inner rocket being about half the length of the outer rocket. The estimation of the respective apolipoprotein A-I concentration for the inner rocket gave, with untreated sera, about 60 to 80 per cent of the tetramethyl urea values. For the outer rocket about 150 per cent of the tetramethyl urea values was observed. With sera heated to $52{ }^{\circ} \mathrm{C}$ the inner rocket would approximately give the same value as obtained after tetramethyl urea treatment, while the outer rocket led to values of 150 per cent and more of the tetramethyl urea values.

Upon staining with oil red only sera delipidated with ether/ethanol were not stained, indicating that the other procedures did not entirely remove the lipid portion. In order to study the reproducibility of both methods, sera with three different concentrations of apolipoprotein A-I, treated with tetramethyl urea, were analysed on ten different days. The coefficients of variation calculated for both methods are shown in table 3. Both methods give fair reproducibility, the EID being slightly superior to the RIA.
Tab. 3. Day to day analysis of apolipoprotein A-I in three different sera by EID and RIA.

\begin{tabular}{|c|c|c|c|c|}
\hline \multicolumn{2}{|l|}{ EID } & \multicolumn{3}{|l|}{ RIA } \\
\hline $\begin{array}{l}\text { Apolipo- } \\
\text { protein } \\
\text { A-I } \\
(\mathrm{mg} / \mathrm{l})\end{array}$ & CV \% & $\begin{array}{l}\text { Apolipo- } \\
\text { protein } \\
\text { A-II } \\
\text { (mg/l) }\end{array}$ & CV\% & Days \\
\hline $\begin{array}{r}690 \\
1040 \\
1230\end{array}$ & $\begin{array}{l}6.0 \\
4.8 \\
3,2\end{array}$ & $\begin{array}{r}650 \\
940 \\
1200\end{array}$ & $\begin{array}{l}9.1 \\
6.9 \\
4.9\end{array}$ & $\begin{array}{l}10 \\
12 \\
12\end{array}$ \\
\hline
\end{tabular}

\section{Discussion}

In view of the increasing amount of evidence indicating that HDL may exert a protective effect against arteriosclerotic vascular lesions its quantitation becomes an important parameter in lipoprotein and lipid diagnostics. At the present time HDL is usually estimated by determining its cholesterol content after separation from the other lipoprotein classes by ultracentrifugation or precipitation. A more direct and more informative approach to the study of the physiological effect of HDL is the quantitative analysis of its apoprotein moiety. Apolipoprotein A-I is the major apolipoprotein of the HDL fraction followed by apolipoprotein A-II and apolipoprotein $\mathrm{E}$. This study presents a comparison between an electroimmunoassay (EID) and a solid phase radioimmunoassay (RIA), previously described by us (9) for the quantitation of apolipoprotein A-I and apolipoprotein A-II. Since the major problem in the quantitative determination of apolipoprotein $\mathrm{A}$ values seems to be the pretreatment of the sera in order to get fully immunoreactive apoproteins, we compared three different procedures for delipidation and denaturation of the sera, namely the delipidation with tetramethyl urea (11) or with an ether/ethanol mixture (10) and heating (5). The various pretreatments led to several differences in 
the behaviour of apolipoproteins A-I and A-II in RIA as well as in EID. In the RIA, native sera and sera delipidated with tetramethyl urea gave similar results for both apoproteins. Upon delipidation with an ether/ ethanol mixture a decrease in apolipoprotein A-I values as compared to data obtained after tetramethyl urea delipidation was noted, while apolipoprotein A-II values determined by RIA were not affected by this pretreatment. Heating to $52{ }^{\circ} \mathrm{C}$ as suggested by Karlin et al. (5) increased the values for both apolipoproteins A-I and A-II, in some cases up to 50 per cent of the tetramethyl urea values. In agreement with a previous report, the RIA method showed an important increase, notably of apolipoprotein A-I values, upon storage of the sera at $4{ }^{\circ} \mathrm{C}$.

In the EID, native sera produced weak and indistinct rockets for both, apolipoprotein A-I and A-II, which were not suitable for quantitative evaluation. Delipidation with ether/ethanol produced a decrease in apolipoprotein A-I levels, similar to that observed in the RIA. In contrast to the RIA, this pretreatment gave an increase of apolipoprotein A-II levels as de termined by EID. Heating finally led to an increase of both apolipoproteins A-I and A-II, as observed in the RIA, but only rockets produced for apolipoprotein A-II were distinct after this pretreatment.

In contrast to the RIA, the EID provides an impression of the various alterations arising after the respective pretreatments of the sera. Staining for lipids indicates that only the delipidation with ether/ethanol leads to lipid-free samples, while the other procedures merely produce a denaturation. EID data indicate that several aggregates are produced by heating, which are visualized by the diffuse and double rockets. The same seems to apply for untreated sera, where these forms probably arise upon storage. It has been shown that storage, like heating, leads to an increase of apolipoprotein A-I as determined by RIA (5).

Provided that similar methods are used for the pretreatment of the sera, our data are in good agreement with data from other authors (4-8). Both methods, RIA and EID, produce comparable results, but reproducibility seems to be slightly higher with the EID. In addition, the EID may be performed in any laboratory with normal electrophoresis equipment, and results may be obtained within a few hours, while the RIA needs a considerably longer time for incubation.

\section{Acknowledgements}

The authors thank Miss $E$. Ischi for excellent technical assistance. This work was supported by a grant from the Swiss National Science Foundation.

\section{References}

1. Miller, G. J. \& Miller, N. E. (1975), Lancet $I, 16-19$.

2. Berg, K., Bфrresen, A.-L. \& Dahlén, G. (1976), Lancet $I$, 499-501.

3. Castelli, W. P., Doyle, J. T., Gordon, T., Hames, C. G., Hjortland, M. C., Hulley, S. B., Kagan, A. \& Zukel, W. J. (1977), Circulation 55, 767-772.

4. Schonfeld, G. \& Pfleger, B. (1974), J. Clin. Invest. 54, 236-246.

5. Karlin, J. B., Juhn, D. J., Starr, J. I., Scanu, A. M. \& Rubenstein, A. H. (1976), J. Lipid Res. 17, 30-37.

6. Assmann, G., Smootz, E., Adler, K., Capurso, A. \& Oette, K. (1977), J. Clin. Invest. 59, 565-575.

7. Fainaru, M., Glangeaud, M. C. \& Eisenberg, S. (1975), Biochim. Biophys. Acta 386, 432-443.

8. Albers, J. J., Wahl, P. W., Cabana, V. G., Hazzard W. R. \& Hoover, J. J. (1976), Metab. Clin. Exp. 25, 633-644.

9. Riesen, W. F., Mordasini, R. C. \& Middelhoff, G. W. (1978), FEBS Letters 91, 35-39.

10. Gotto, A. M. \& Kon, H. (1970), Biochemistry 9, 4276-1482.

11. Kane, J. P. (1973), Anal. Biochem. 53, 350-364.

12. Havel, J. J., Eder, H. A. \& Bragdon, S. H. (1955), J. Clin. Invest. 34, 1345-1354.

13. Jackson, R. L. \& Gotto, A. M. (1972), Biochim. Biophys. Acta 285, 36-47.

14. Shore, B. \& Shore, V. (1969), Biochemistry 8, 4510-4516.

15. Lux, S. E., John, K. M. \& Brewer, H. B. jr. (1972), J. Biol. Chem. 247, 7510-7518.

16. Scanu, A. M., Toth, J., Edelstein, C., Koga, S. \& Stiller, E. (1969), Biochemistry 8, 3309-3316.

17. Cuatrescasas, P. (1970), J. Biol. Chem. 245, 3059-3065.

18. Lowry, O. H., Rosebrough, N. J., Farr, A. I. \& Randall, R. J. (1951), J. Biol. Chem. 193; 265-275.
Dr. R. C. Mordasini

Institute for Cinical Protein Research University of Berne, Tiefenau-Hospital CH-3004 Berne

Switzerland 